\title{
Physical Modelling Of Improving Bearing Capacity For Foundations By Geo Fabrics
}

\author{
Joy Ghosh, Dr. Jay Meegoda \\ (Civil Engg Dept., Heritage Institute Of Technology, Kolkata, India) \\ ( Phd,P.E.,Civil Engg Dept., New Jersey Institute Of Technology, Newark, USA)
}

\begin{abstract}
The objective of the research paper is to develop a new model by which we can improve the bearing capacity of foundation by using geo fabrics. The primary design concerns for a foundation engineer are bearing capacity and settlement. The soil reinforcement technique of the geo synthetic has been taken into account for developing such a model that can be used to reduce excessive settlements on soft soils and prevent the foundation from failing. Hence, this paper summarizes the physical and numerical simulation to verify the results to enhance the performance of the foundation.
\end{abstract}

Motivation: With the rapid increase in globalization, there has been a shortage of land. Deep foundations are required for poor soil conditions, sloping lands and where there is problems regarding site drainage. Besides with rising cost of materials and increased labor and time required for construction, it has become the need of the hour to develop a new model that will do away with the traditional materials, increase the bearing capacity, and reduce settlement to construct the foundations. The geo synthetics are the third revolution in civil engineering materials that has taken the world by surprise. Its increasing usage owing to its non biodegradable ness, durability, increasing the factor of safety and cost effectiveness can be used to develop a model that would increase the bearing capacity of foundations. Besides, in places where deep foundations are used for poor soil conditions and drainage problems, we can use this new cost effective model of shallow foundation with geofabrics that results in increased bearing capacity.

\section{Introduction:}

The primary design criteria for a foundation are bearing capacity and settlement. The use of geo synthetic material to improve the bearing capacity and the settlement performance of a shallow foundation has been of much interest to geotechnical engineers. Several research works has been carried out for soil improvement using several geosynthetic materials. Binquet and Lee used metallic strip under strip footing to improve its bearing capacity. Geogrids and geo cells were later on used for such work. From the finding of numerous researchers, it can be concluded that the bearing capacity of soil also changed with various factors like type of reinforcing materials, number of reinforcement layers, ratios of different parameters of reinforcing materials, and foundations such as footing width, location of the 1st layer of reinforcement to width of footing and vertical spacing between consecutive geogrid layer. However, not much appreciable work has been done with geofabrics to improve the bearing capacity of foundations. The ratio of improvement in the bearing capacity can be expressed in a non dimensional form as bearing capacity ratio (BCR) which is the ratio of bearing capacity of reinforced soil to bearing capacity of unreinforced soil. The present study investigates the improvement of bearing capacity of shallow foundations with the utilization of geofabrics.

\section{OBJECTIVE:}

1. To improve the bearing capacity of foundations with the help of geo fabric

2. To determine the place where the geo fabric should be placed.

3. To determine the reason behind the increase in bearing capacity.

4. To validate the results using physical simulation.

\section{Literature Review:}

The use of geo synthetic materials to improve the bearing capacity and settlement performance of shallow foundation has gained attention in the field of geotechnical engineering. For the last three decades, several studies have been conducted based on the laboratory model and field tests, related to the beneficial effects of the geosynthetic materials, on the load bearing capacity of soils in the road pavements, shallow foundations, and slope stabilizations.

The first systematic study to improve the bearing capacity of strip footing by using metallic strip was by Binquet and Lee. After Binquet and Lee's work, several studies have been conducted on the improvement of load bearing capacity of shallow foundations supported by sand reinforced with various reinforcing materials 
such as geogrids ( Milligan and Love1984,1985, Khing et al. 1993, Ismail and Raymond 1995, A. Rahman AlSinaidi and Ashraf Hassan Ali ),geo textiles and geo membranes (V.K.Puri, E.E.Cook, S.C.Yen, B.M.Das, K.H.Khing,1993) metal strips and geo cell [17, 18] M.S. Ranadive and N.N.Jadhav carried their research for soil improvement by the use of geo textiles. R. Kerry Rowe and C.T. Gnanendran made an extensive study on reinforced embankment with the help of geo textiles.

\section{THEORY:}

A foundation is the lowest and supporting layer of any structure which forms the interface across which the loads are transmitted to the underlying soil or rock.

Foundations are classified as:

a) Shallow foundation: It is a case where depth of the foundation is less than or equal to the width of the foundation

b) Deep foundation: In this foundation, the depth of the foundation is more than the width of the foundation.

Design criteria for a foundation:

a) Adequate Depth: The depth of the foundation must be sufficient to prevent the conditions on ground surface from affecting the foundation.

b) Bearing Capacity: The soil must be strong enough to withstand the load coming from the foundation.

c) Limiting Settlement: The acceptable settlement of the structure should not exceed the settlement of the foundation.

Bearing capacity: It is the maximum contact pressure between foundation and soil that should not produce any shear in soil.

Ultimate bearing capacity: It is the value of bearing stress which causes a sudden catastrophic settlement of the foundation (due to shear failure).

Allowable bearing capacity $\left(\mathrm{q}_{\mathrm{a}}\right)$ : It is the maximum bearing stress that can be applied to the foundation such that it is safe against instability due to shear failure and the maximum tolerable settlement is not exceeded. The allowable bearing capacity is normally calculated from the ultimate bearing capacity using a factor of safety $\left(\mathrm{F}_{\mathrm{s}}\right)$.

When excavating for a foundation, the stress at founding level is relieved by the removal of the weight of soil. The net bearing pressure $\left(\mathrm{q}_{\mathrm{n}}\right)$ is the increase in stress on the soil. $\mathrm{q}_{\mathrm{n}}=$ q $\mathrm{q}_{\mathrm{o}}=\gamma \square \mathrm{D}$

where $\mathrm{D}$ is the founding depth and $\gamma$ is the unit weight of the soil removed.

\section{TERZAGHI'S ULTIMATE BEARING CAPACITY THEORY \\ III. Bearing Capacity}

* Shallow Strip Footings

$\mathbf{Q u}=\mathbf{c}(\mathrm{Nc})+\gamma(\mathbf{D})(\mathbf{N q})+\mathbf{0 . 5} \gamma(\mathbf{B})(\mathrm{N} \gamma)(\mathrm{kN} / \mathrm{m} 2)(\mathrm{lb} / \mathrm{ft} 2)$

* Shallow Square Footings

$\mathbf{Q u}=\mathbf{1 . 3 c}(\mathrm{Nc})+\gamma(\mathbf{D})(\mathrm{Nq})+\mathbf{0 . 4} \gamma(\mathbf{B})(\mathrm{N} \gamma)(\mathrm{kN} / \mathrm{m} 2)(\mathrm{lb} / \mathrm{ft} 2)$

* Shallow Circular Footings

$\mathbf{Q u}=\mathbf{1 . 3} \mathbf{c}(\mathrm{Nc})+\gamma(\mathbf{D})(\mathbf{N q})+\mathbf{0 . 3} \gamma(\mathbf{B})(\mathbf{N} \gamma)(\mathrm{kN} / \mathrm{m} 2)(\mathrm{lb} / \mathrm{ft} 2)$

\section{Ground failure modes:}

(a) GENERAL SHEAR FAILURE

* Continuous shear formation occurs up to ground level with heave

* Soil possesses high shear strength.

(b) LOCAL SHEAR FAILURE

* Slight heaving with compression under footing.

* Soil possesses medium shear strength.

(c)PUNCHING SHEAR FAILURE

* Vertical slip surfaces with large vertical displacements.

* Soil has low shear strength. 


\section{Geo synthetics:}

The geo synthetics are man made polyester materials that is non bio degradable. They are non corrodible, Increase the safety factor, improve performance, and reduce costs. They are non-corrodible, nonbiodegradable and stable in both acidic and alkaline environments.

Geo synthetics have taken the world by surprise. Its increasing durability, reliability, cost effectiveness and eco friendliness has proven to be much of a success, so it could be used as the best alternative to conventional materials that used in foundation.

Geosynthetics has got a wide range of activities in civil engineering. It is because of the following functions:
a) Reinforcement
b) Separation
c) Filtration
d) Drainage
e) Fluid Barrier
f) Protection

\section{Reinforcement:}

It enhances the mechanical properties of a soil mass as a result of its inclusion. The reinforced soil possesses high compressive and tensile strength.

\section{Separation:}

It prevents intermixing of dissimilar soil and fill materials during construction and over a projected service lifetime of the application under construction.

\section{Filtration:}

It allows for adequate fluid flow with limited migration of soil particles across its plane over a projected service lifetime of the application under consideration.

\section{Drainage:}

The geosynthetic system allows for adequate liquid flow without soil loss, within the plane of the geosynthetic over a service lifetime compatible with the application under consideration.

\section{Fluid Barrier:}

It prevents the migration of liquids or gases over a projected surface.

\section{Protection:}

When it alleviates or distributes stresses and strains transmitted to the material to be protected any damage.

\section{Geofabrics:}

These are continuous sheets of woven, non-woven or knitted fibers may be used as a filter for a gravel drain on top of the liner. A fabric may be used to reinforce a landfill

- Function: Filtration, Reinforcement.

- Properties: permeability, pore sizes, tensile strength, durability.

\section{SOIL-GEOSYNTHETICS INTERACTION}

The geo synthetic reinforced foundation soil provide improved load bearing capacity and reduce settlements by distributing the imposed loads over a wide area of weak subsoil, thus limiting the use of granular soils. Reinforced soil possesses high shear strength. The geosynthetic acts as a tensioned member coupled to the soil material by friction, adhesion and confinement, thus maintaining stability of the soil.

\section{PHYSICAL SIMULATION}

For our research, we used the centrifuge to develop a read life model to which the foundation had been projected to the centrifugal force. We tried with several models and experimented with different geo synthetics to get the results. Our primary target was to achieve an improvement in bearing capacity of foundations with the aid of geo fabrics. 


\section{MATERIALS USED:}

Soil:

A mixture of two types of clayey soil - Kaolinite and Rock Flour were used for the research work. The collected soil was dried, mixed by volume of $50 \%$ each and then passed through US sieve \# 40. The properties of soil were determined by performing the following tests in the laboratory.

The unconfined compressive test was used to find out the cohesion and elastic modulus of the soil.

Given below are the results:

\begin{tabular}{llll}
$\begin{array}{l}\text { Water } \\
\text { Content } \\
(\%)\end{array}$ & Capacity & Ultimate Bearing & \multicolumn{2}{c}{ Modulus of } \\
$\left(\mathrm{lb} / \mathrm{in}^{\wedge} 2\right)$ & Elasticity & $\left(\mathrm{lb} / \mathrm{in} \mathbf{n}^{\wedge}\right)$
\end{tabular}

$16-6.16$

Test 2

Test 3

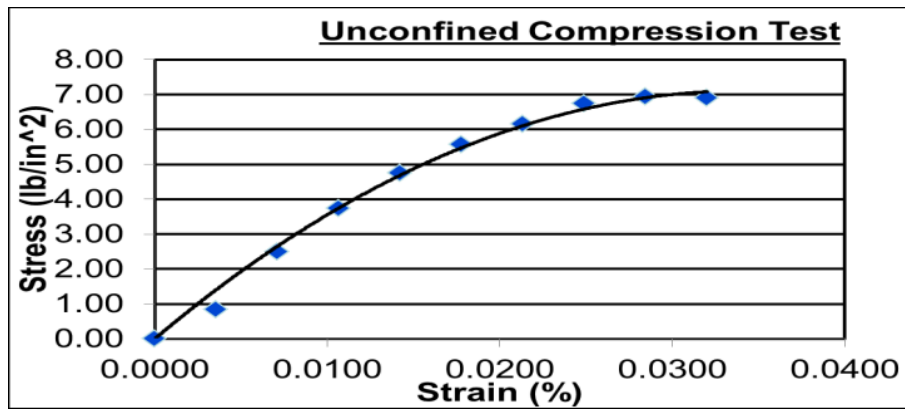

UNCONFINED COMPRESSION TEST FOR $16 \%$

The standard proctor test was used to find the unit weight (both dry and wet) of soil at $16 \%$.

Given below are the results:

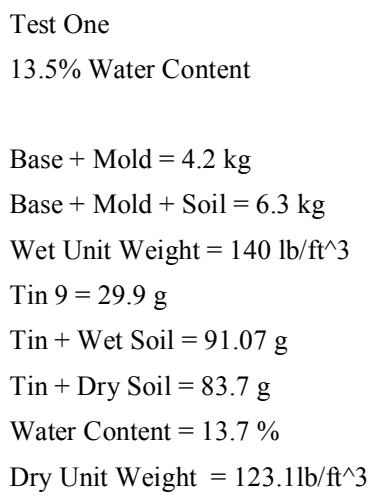

Test Three

$8 \%$ Water Content

Base + Mold $=4.2 \mathrm{~kg}$

Base + Mold + Soil $=6.00 \mathrm{~kg}$

Wet Unit Weight $=120 \mathrm{lb} / \mathrm{ft}^{\wedge} 3$

Tin $\mathrm{J} 3=30.61 \mathrm{~g}$

Tin + Wet Soil $=96.37 \mathrm{~g}$

Tin + Dry Soil $=90.6 \mathrm{~g}$

Water Content $=9.6 \%$

Dry Unit Weight $=109.5 \mathrm{lb} / \mathrm{ft}^{\wedge} 3$
Test Two

11\% Water Content

Base + Mold $=4.2 \mathrm{~kg}$

Base + Mold + Soil $=6.2 \mathrm{~kg}$

Wet Unit Weight $=133.3 \mathrm{lb} / \mathrm{ft}^{\wedge} 3$

Tin $3=29.49 \mathrm{~g}$

Tin + Wet Soil $=116.52 \mathrm{~g}$

Tin + Dry Soil $=107.1 \mathrm{~g}$

Water Content $=12.1 \%$

Dry Unit Weight $=118.9 \mathrm{lb} / \mathrm{ft}^{\wedge} 3$

Test Four

16\% Water Content

Base + Mold $=4.2 \mathrm{~kg}$

Base + Mold + Soil $=6.15 \mathrm{~kg}$

Wet Unit Weight $=130 \mathrm{lb} / \mathrm{ft}^{\wedge} 3$

Tin $4=30.0 \mathrm{~g}$

Tin + Wet Soil $=115.1 \mathrm{~g}$

Tin + Dry Soil $=102.1 \mathrm{~g}$

Water Content $=18 \%$

Dry Unit Weight $=110.2 \mathrm{lb} / \mathrm{ft}^{\wedge} 3$ 
Below are the listed soil properties:

\section{Soil properties:}

Contents:

$50 \%$ kaolinite $\quad 50 \%$ rock flour (by volume)

Color:

White

Odor:

None

Texture:

Soft

Friction angle:

Average Cohesion:

Water content:

Modulus of elasticity: $\quad 477.95 \mathrm{psi}$

$4.0 \mathrm{psi}$

Ultimate bearing capacity:

Wet unit weight:

Dry unit weight:

$$
\left.137.9 \mathrm{lb} / \mathrm{in}^{\wedge} 3 \text { (at } 16 \%\right)
$$

$119.1 \mathrm{lb} / \mathrm{in}^{\wedge} 3($ at $16 \%)$

\section{The choice of water content:}

Few tests were even conducted in the centrifuge with different types of moisture content from which we arrived at the following conclusions for our reason to sticking to $16 \%$ water content.

\section{Soil of low water content:}

The soil sample was found out to be stiff, dry and hard. The test when it was performed the model used to reach, higher values of dial reading on the centrifuge. Thus soil already has high bearing capacity. Foundations used to topple over when base was uneven.

As we are interested in improving the bearing capacity of soils, we discarded this as our target is poor soil conditions.

\section{Soil of high water content:}

The soil sample was very soft and moist. Cracks developed after the test through which water came out to the surface. The centrifuge did not achieve much dial reading. This sample had low bearing capacity.

We discard this model as this scenario does not occur in real life and water oozes out, so we do not go forward with it.

\section{Optimum water content chosen: $16 \%$}

The soil wasn't stiff nor did water come out to the surface. Besides the standard proctor test and the unconfined compression test was performed

\section{Geofabrics:}

Different geosynthetic used for the test:

1. Metal Screen :

2. Woven Geo fabric

3. Non woven black geo fabric

4. Non woven white geo fabric

Summary of results with the different geo fabric used:

\section{Metal Screen:}

The metal screen used was grey in color and had a thickness of 0.0188 inch. Since it is metallic and a non geo synthetic material, it did not meet our criteria for performing the test.

\section{Woven Geo fabric:}

The woven geo fabric used was green in color and had a thickness of 0.025 inch. It did not allow water to seep down. So the upper layer of soil used to stay moist. It did not attain much dial reading on the centrifuge even.

\section{Non woven black Geo fabric:}

The non woven geo fabric had a thickness of 0.025 inch and was black in color. It allowed water to pass through it and so it gave better results than the woven geofabrics. However, it did not reach the max dial reading of 7 in the centrifuge. 


\section{Non woven white geo fabric:}

This non woven geo fabric had a thickness of 0.025 inch and was white in color. It allowed water to pass through it. It gave better results than the black non woven geofabrics as the dial reading reached 7 on the centrifuge.

\section{Centrifuge:}

The centrifuge is used to provide centrifugal force. It provides a real life scenario by which $\mathrm{g}$ force can be applied to the original model. The centrifuge consists of two swinging buckets in which a camera is fitted on to it. The dial reading in centrifuge is calculated by the stroboscope test which in turn indicates the various $g$ force values with different dial readings. The model is subjected to the centrifugal force perpendicular to its axis. The centrifuge is used to provide a $\mathrm{g}$ force as: (distance* $\left.\left(\mathrm{RPM}^{\wedge} 2\right)\right) /$ acceleration due to gravity. Load is increased due to centripetal force up to 41.5 times the load.

The swinging buckets in which the model is made had the dimensions of Length:12.3 inch, Width : 10 inches. The wall thickness was 1 inch. A camera was fitted inside the centrifuge which was connected to the monitor to get a visualization of the model in focus. The swinging bucket is made up of iron so that it acts as a hard base stratum of rocks beneath the soil layer. The results were multiplied with 41.5 times(which was got from the stroboscope) to get the real value.

The stroboscope was used to relate the dial reading with the $\mathrm{g}$ force.

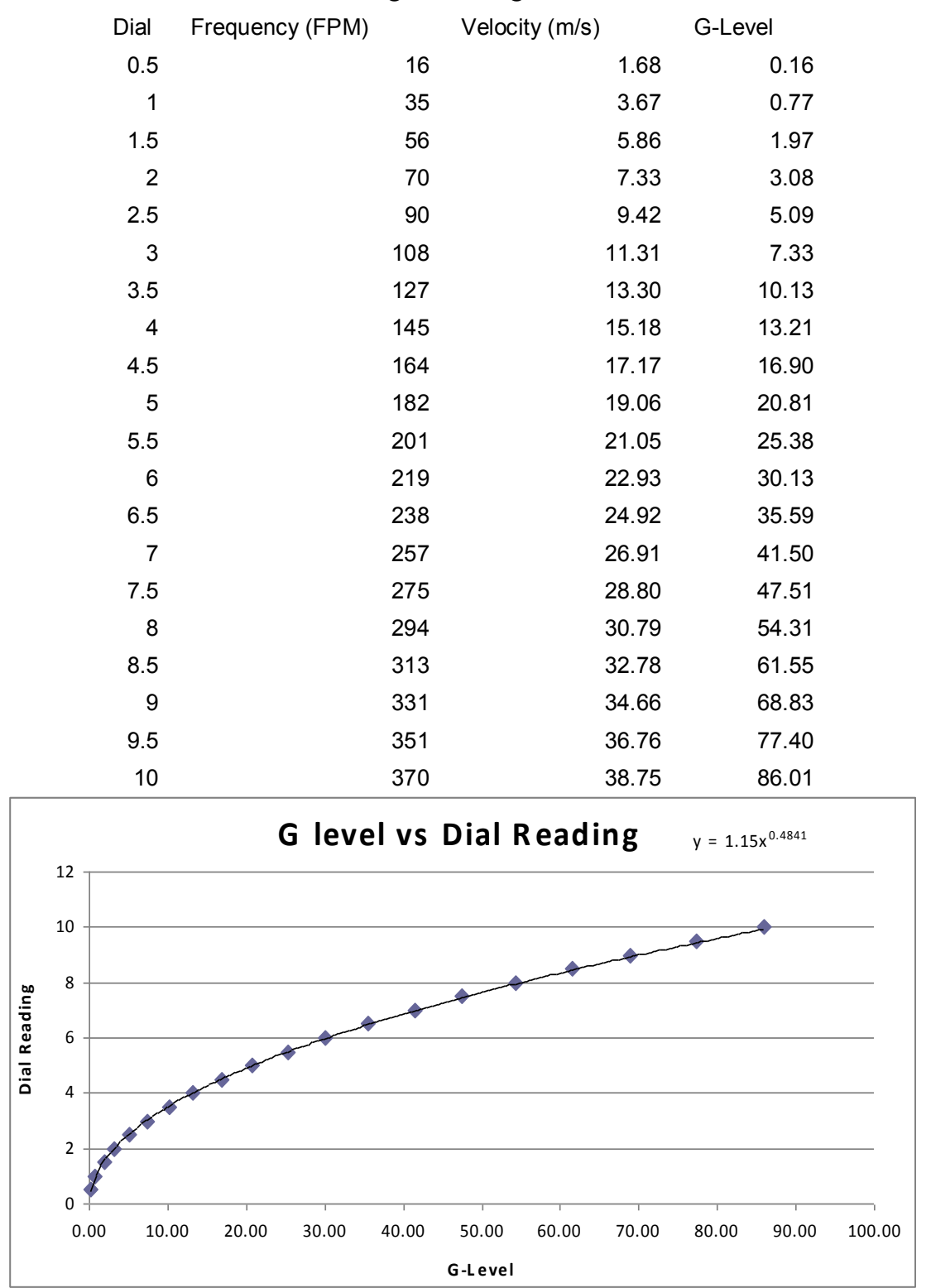

G-LEVEL VS DIAL READING 
Footings:

Two types of footings are used for the experiments. They are:

1. Small cylindrical footing of diameter 1 inch having a mass of 177.2 grams.

2. A bigger cylindrical foundation of diameter 2.3 inches and a mass of 1157 grams.

\section{PRIMARY METHODOLOGY:}

The soil containing 50\% kaolinite and $50 \%$ rock flour was first mixed dryly. When older soil was used, the bigger particles were broken down into smaller ones by mortar. It was made oven dry. Then it was passed through US sieve \# 40. The weight was found out, and accordingly water was added to achieve a water content of $16 \%$. Then, the soil was mixed thoroughly. We used to place 3 kilograms of soil in four layers in each bucket for the test. Each layer was compacted thirty-five times by the standard compactor hammer to make the surface uniform. The bucket was then put in the centrifuge and the test was run.

The geofabric which was used had the dimensions of 12.5 inch $* 10$ inch *.025 inch. It was generally placed in the $3^{\text {rd }}$ layer from the bottom (or just one layer down from the top). However, later on it was placed in the model as per the requirement. At the end of every day's test, a sample of soil from the bucket was put in the oven for 24 hours, for measuring the water content.

\section{EXPERIMENTAL STUDY:}

\section{Sample Test 1:}

We placed a single foundation of radius 0.5 inch and mass of 177.2 grams on the top layer of soil and performed the test. The monitor was used to keep a track of the effect of the centrifuge of the foundation. The dial reading in the centrifuge was increased slowly without any stoppages. As soon as the foundation fell, the centrifuge was put off. The test was done without geofabric and then with different types of geofabrics. We placed the foundation in different positions on the top soil, keeping a gap of more than 1.414 (root 2) time the diameter from each other, so that it did not lie within the passive zone of the foundation.

1. No Geofabric

\section{Results:}

\begin{tabular}{lrlrlll} 
Bucket One & \multicolumn{1}{l}{$\begin{array}{l}\text { Dial } \\
\text { Reading }\end{array}$} & \multicolumn{2}{l}{$\begin{array}{l}\text { Force } \\
\text { (grams) }\end{array}$} & \multicolumn{1}{l}{$\begin{array}{l}\text { Water } \\
\text { Content }\end{array}$} & $\begin{array}{l}\text { Geosynthetic } \\
\text { Septh of }\end{array}$ & $\begin{array}{l}\text { Weight of } \\
\text { Soil }\end{array}$ \\
Test One & 2.75 & 1099.8 & $17.3 \%$ & None & 2.5 inches & $177.2 \mathrm{~g}$ \\
Test Two & 3.2 & 1501.1 & $17.3 \%$ & None & 2.5 inches & $177.2 \mathrm{~g}$ \\
Test Three & 3.2 & 1501.1 & $17.3 \%$ & None & 2.5 inches & $177.2 \mathrm{~g}$ \\
Test Four & 3.3 & 1598.7 & $17.3 \%$ & None & 2.5 inches & $177.2 \mathrm{~g}$ \\
Test Five & 3.2 & 1501.1 & $17.3 \%$ & None & 2.5 inches & $177.2 \mathrm{~g}$
\end{tabular}

2. Geo grid

\begin{tabular}{|c|c|c|c|c|c|c|}
\hline $\begin{array}{l}\text { Bucket } \\
\text { Two }\end{array}$ & $\begin{array}{l}\text { Dial } \\
\text { Reading }\end{array}$ & $\begin{array}{l}\text { Force } \\
\text { (grams) }\end{array}$ & $\begin{array}{l}\text { Water } \\
\text { Content }\end{array}$ & Geosynthetic & $\begin{array}{l}\text { Depth of } \\
\text { Soil }\end{array}$ & $\begin{array}{l}\text { Weight of } \\
\text { Foundation }\end{array}$ \\
\hline Test One & 3.6 & 1910.1 & $17.2 \%$ & OL GG & 2.5 inches & $177.2 \mathrm{~g}$ \\
\hline Test Two & 3.9 & 2249.1 & $17.2 \%$ & OL GG & 2.5 inches & $177.2 \mathrm{~g}$ \\
\hline Test Three & 4.0 & 2368.3 & $17.2 \%$ & OL GG & 2.5 inches & $177.2 \mathrm{~g}$ \\
\hline Test Four & 3.65 & 1964.7 & $17.2 \%$ & OL GG & 2.5 inches & $177.2 \mathrm{~g}$ \\
\hline \multicolumn{7}{|l|}{ Geofabric } \\
\hline $\begin{array}{l}\text { Bucket } \\
\text { Two }\end{array}$ & $\begin{array}{l}\text { Dial } \\
\text { Reading }\end{array}$ & $\begin{array}{l}\text { Force } \\
\text { (grams) }\end{array}$ & $\begin{array}{l}\text { Water } \\
\text { Content }\end{array}$ & Geosynthetic & $\begin{array}{l}\text { Depth of } \\
\text { Soil }\end{array}$ & $\begin{array}{l}\text { Weight of } \\
\text { Foundation }\end{array}$ \\
\hline Test One & 2.5 & 903.8 & $17.2 \%$ & OL WGF & 2.5 inches & $177.2 \mathrm{~g}$ \\
\hline Test Two & 3.6 & 1910.1 & $17.2 \%$ & OL WGF & 2.5 inches & $177.2 \mathrm{~g}$ \\
\hline Test Three & 4.2 & 2615.8 & $17.2 \%$ & OL WGF & 2.5 inches & $177.2 \mathrm{~g}$ \\
\hline Test Four & 2.9 & 1226.7 & $17.2 \%$ & OL WGF & 2.5 inches & $177.2 \mathrm{~g}$ \\
\hline
\end{tabular}

4. Non woven Black Geofabric

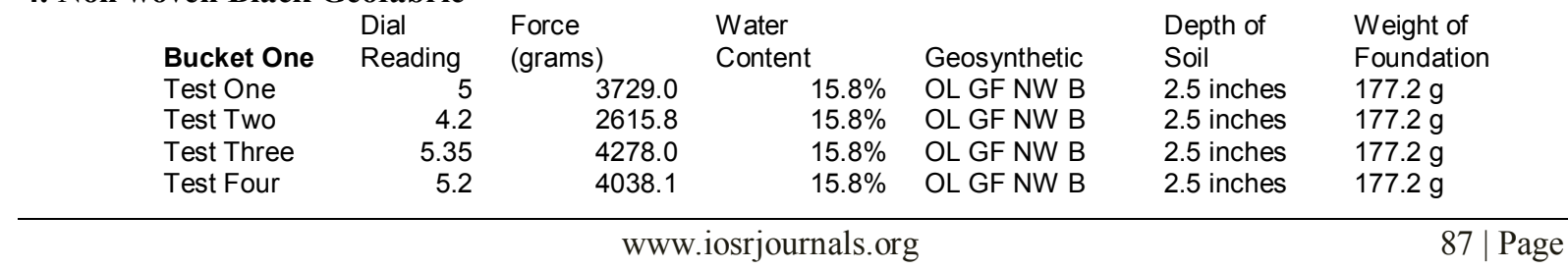




\section{Non woven White Geofabric}

\begin{tabular}{|c|c|c|c|c|c|c|}
\hline Bucket Two & $\begin{array}{l}\text { Dial } \\
\text { Reading }\end{array}$ & $\begin{array}{l}\text { Force } \\
\text { (grams) }\end{array}$ & $\begin{array}{l}\text { Water } \\
\text { Content }\end{array}$ & Geosynthetic & $\begin{array}{l}\text { Depth of } \\
\text { Soil }\end{array}$ & $\begin{array}{l}\text { Weight of } \\
\text { Foundation }\end{array}$ \\
\hline Test One & 3.1 & 1406.6 & $15.8 \%$ & OL GF NW W & 2.5 inches & $177.2 \mathrm{~g}$ \\
\hline Test Two & 5.2 & 4038.1 & $15.8 \%$ & OL GF NW W & 2.5 inches & $177.2 \mathrm{~g}$ \\
\hline Test Three & 5.75 & 4951.4 & $15.8 \%$ & OL GF NW W & 2.5 inches & $177.2 \mathrm{~g}$ \\
\hline Test Four & 6 & 5397.3 & $15.8 \%$ & OL GF NW W & 2.5 inches & $177.2 \mathrm{~g}$ \\
\hline
\end{tabular}

\section{Conclusions:}

It is observed that for the model without the geo fabrics, the foundation did not last long on the centrifuge. For the geogrid, the results showed slight improvement. When the woven geo fabric was used, water used to seep to the top surface. It did not give satisfactory results even. Then we used the non woven geo fabrics, which gave the desired results as the foundation lasted for long in the centrifuge before toppling over. The white geo fabric gave the best results as the foundation lasted till dial reading 6 on the centrifuge.

Thus, the bearing capacity increased significantly for all the reinforced soil as compared to the soil without geofabric. The woven geo fabric acted as a barrier for the transmission of water in the soil from the top layers to the bottom layers, so it acted as a fluid barrier. Thus, we could not use this geo fabric for further tests. The non woven geo fabric had a BCR of around 4 . This white geo fabric fulfilled our objective that the bearing capacity could be increased much if the geo fabric was used.

However we could not arrive at the settlement analysis. We did not proceed with such a model as the radius of influence was too small and no load was applied to the foundation. Besides, failure was determined when the foundation toppled over which might have occurred due to the foundation being non eccentric and it got swayed due to the large centripetal force of the centrifuge. Besides, there weren't any appreciable settlement beneath the foundation. So we discarded this model.

\section{Sample Test 2:}

We used the bigger foundation this time to perform our test. Since, in real life a foundation did not fail just by toppling over, but due to settlement we proceeded with this model.

At first we recorded and calibrated data using LVDT for finding out a relationship between the voltage applied and the displacement. The following results were obtained:

We fixed the LVDT (linear variable differential transformer) on a metallic strip that was placed over the foundation and performed the test. We connected the LVDT to an A-D converter which was connected to the computer. We used the DASYLAB software for getting the results while running the test. Failure was determined at a certain voltage that corresponded to $10 \%$ of the total depth of the soil layer, the total depth generally being 2.5 inches. We used to keep the model at each dial reading around for 5 minutes. The other bucket had the same model fitted with a non functioning LVDT so as to keep the weights same on both arms of the lever. However, it did not fail even after running the test to dial reading 7 on the centrifuge. The test was done with both un reinforced and reinforced soil.

We then tried the tests by putting different weights over the foundations like 4,8,12 and $16 \mathrm{kgs}$ in both the buckets fitted with the LVDT and performed the test. This time the impression that occurred under the foundation was greater was much more yet it did not fail, that is it did not reach $10 \%$ of the total depth of the soil thickness. The geofabric was placed in the $3^{\text {rd }}$ layer for the reinforced soil while the test was even carried out with un reinforced soil

\section{Conclusions:}

We arrived at the conclusion that the foundation with the geofabric gave better results than the model without the geo fabric as the un reinforced soil had more settlement than the reinforced soil. Besides; there was a prominent impression beneath the foundation for settlement which did not happen in the earlier cases. Thus the bearing capacity increased for the reinforced soil. In this model, we could even apply loads and the foundation did not topple over. However, we did not proceed with this model as the foundation did not fail owing to the increase in weight of the foundation and its larger dimension. It did not reach $10 \%$ of its total depth. It was so as the radius of influence of the foundation hit the bottom of the bucket.

\section{Main Test:}

We finally arrived at our required model where we used four foundations of diameter 1 inch each in each bucket and placed them in the top layer. The load was placed in such a manner that the four foundations lay under the four different corners of the load. We used two different types of loads of $8 \mathrm{kgs}$ and $16 \mathrm{kgs}$. The water content of the soil was kept at $16 \%$ when it was mixed and used for the test. We tried our test without the 
geofabric, then we placed the geofabric at the $3^{\text {rd }}$ layer and then as per our requirement. As earlier the soil was placed in 4 layers having a mass of $3 \mathrm{kgs}$ each and each layer was compacted 35 times to make the surface even. When the geo fabric was placed at the middle of any layer, soil of $1.5 \mathrm{kgs}$ were first placed, the surface was made uniform just by a gentle touch by the lower side of the hammer, then the geofabric was placed. Over it, the rest of $1.5 \mathrm{kgs}$ of soil mass was spread and then it was compacted by giving 35 numbers of blows. A weight test was even carried out to see how much load the foundations could carry and with what settlement. However, it could take up to $100 \mathrm{kgs}$, then the weights fell off. The model was kept at each dial reading for 1 minute, and then settlement analysis was done using vernier calipers. The depth of soil was also measured using this device.

The calculations of the G-weight were done corresponding to the centrifuge dial reading as previously found out by the stroboscope. It could be related as:

\begin{tabular}{|c|c|c|c|}
\hline Dial & Frequency (FPM) & Velocity $(\mathrm{m} / \mathrm{s})$ & G-Level \\
\hline 0.5 & 16 & 1.68 & 0.16 \\
\hline 1 & 35 & 3.67 & 0.77 \\
\hline 1.5 & 56 & 5.86 & 1.97 \\
\hline 2 & 70 & 7.33 & 3.08 \\
\hline 2.5 & 90 & 9.42 & 5.09 \\
\hline 3 & 108 & 11.31 & 7.33 \\
\hline 3.5 & 127 & 13.30 & 10.13 \\
\hline 4 & 145 & 15.18 & 13.21 \\
\hline 4.5 & 164 & 17.17 & 16.90 \\
\hline 5 & 182 & 19.06 & 20.81 \\
\hline 5.5 & 201 & 21.05 & 25.38 \\
\hline 6 & 219 & 22.93 & 30.13 \\
\hline 6.5 & 238 & 24.92 & 35.59 \\
\hline 7 & 257 & 26.91 & 41.50 \\
\hline 7.5 & 275 & 28.80 & 47.51 \\
\hline 8 & 294 & 30.79 & 54.31 \\
\hline 8.5 & 313 & 32.78 & 61.55 \\
\hline 9 & 331 & 34.66 & 68.83 \\
\hline 9.5 & 351 & 36.76 & 77.40 \\
\hline 10 & 370 & 38.75 & 86.01 \\
\hline
\end{tabular}

The following tests were done:

a) No of geofabric: One

Depth of geofabric: 0.875 inch

Depth of soil: 3.5 inch

Weights placed: $12 \mathrm{kgs}$

\begin{tabular}{|c|c|c|c|c|c|c|}
\hline Settlement & $\begin{array}{l}\text { Dial } \\
\text { Reading }\end{array}$ & $\begin{array}{l}\text { Force } \\
\text { (grams) }\end{array}$ & $\begin{array}{l}\text { Water } \\
\text { Content }\end{array}$ & Geosynthetic & $\begin{array}{l}\text { Depth of } \\
\text { Soil }\end{array}$ & $\begin{array}{l}\text { Weight of } \\
\text { Foundation }\end{array}$ \\
\hline 0.075 & 1 & 9423.3 & $15.1 \%$ & One & 3.5 inches & 12709.5 \\
\hline 0.075 & 2 & 40843.1 & $15.1 \%$ & One & 3.5 inches & 12709.5 \\
\hline 0.125 & 3 & 94322.6 & $15.1 \%$ & One & 3.5 inches & 12709.5 \\
\hline 0.175 & 4 & 169861.8 & $15.1 \%$ & One & 3.5 inches & 12709.5 \\
\hline 0.275 & 5 & 267460.7 & $15.1 \%$ & One & 3.5 inches & 12709.5 \\
\hline \multirow[t]{2}{*}{0.4125} & 6 & 387119.2 & $15.1 \%$ & One & 3.5 inches & 12709.5 \\
\hline & 7 & 528837.4 & $15.1 \%$ & One & 3.5 inches & 12709.5 \\
\hline
\end{tabular}




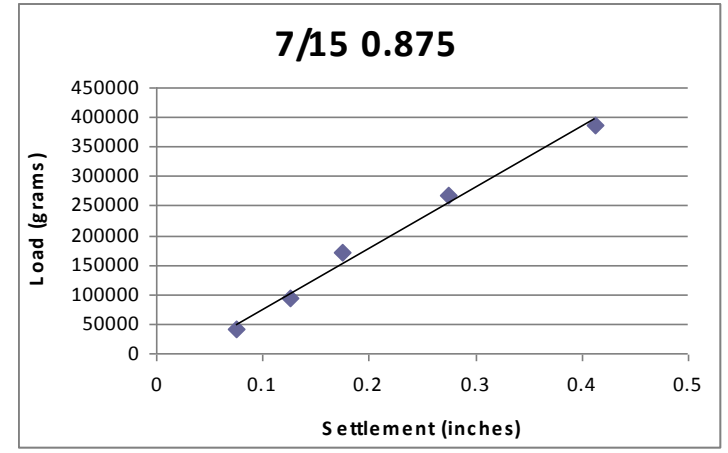

Bearing Capacity: 125.7 psi

b) Number of geofabric: One

Depth of geofabric: 0.875 inch

Weights placed: $16 \mathrm{kgs}$

Depth of soil: 3.5 inches

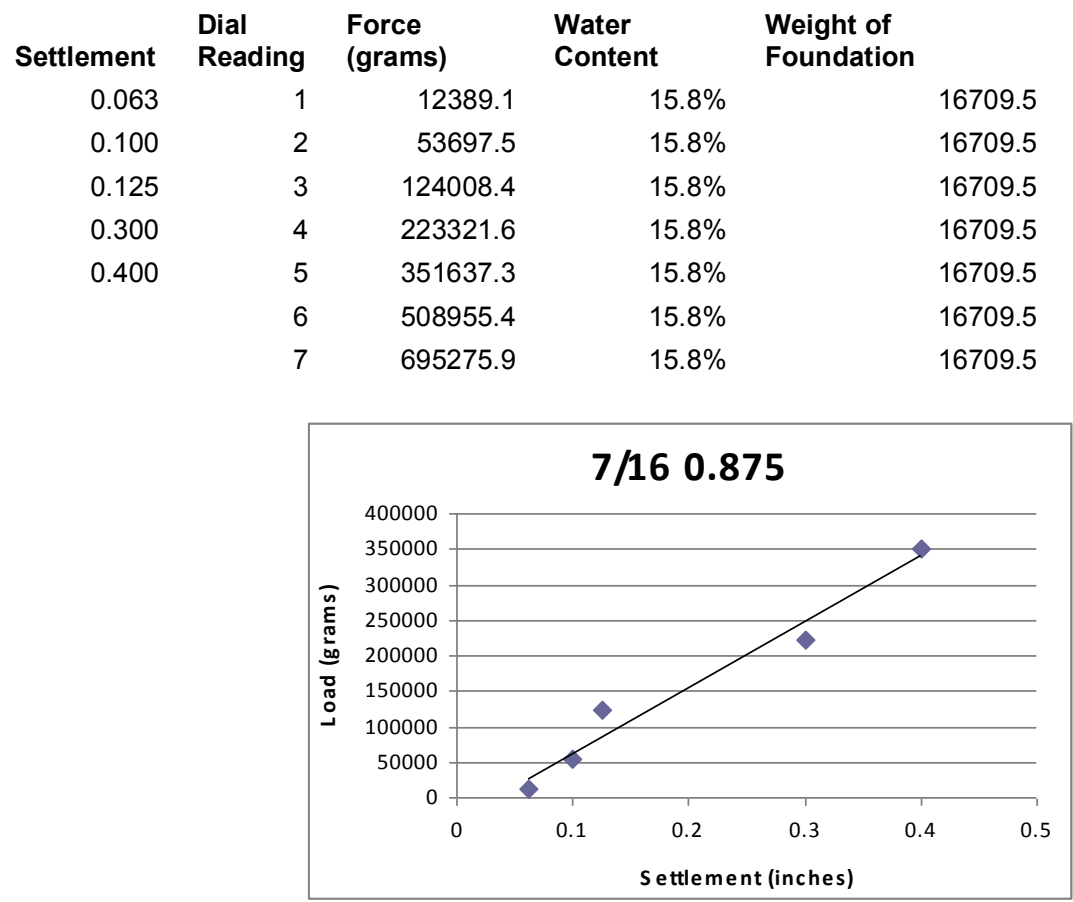

Bearing Capacity: 109.0 psi

c) Number of geofabric: One

Depth of geofabric: 0.875 inch

Weights placed: $12 \mathrm{kgs}$

Depth of soil: 3.5 inch

\begin{tabular}{|c|c|c|c|c|c|c|}
\hline Settlement & $\begin{array}{l}\text { Dial } \\
\text { Reading }\end{array}$ & $\begin{array}{l}\text { Force } \\
\text { (grams) }\end{array}$ & $\begin{array}{l}\text { Water } \\
\text { Content }\end{array}$ & Weight of Foundation & $\begin{array}{l}\text { G- } \\
\text { Weight }\end{array}$ & $\begin{array}{l}\text { Weight of } \\
\text { Everything }\end{array}$ \\
\hline 0.063 & 1 & 9423.3 & $16.1 \%$ & 12709.5 & 61.44 & 36.2095 \\
\hline 0.100 & 2 & 40843.1 & $16.1 \%$ & 12709.5 & 245.75 & 36.2095 \\
\hline 0.125 & 3 & 94322.6 & $16.1 \%$ & 12709.5 & 585.00 & 36.2095 \\
\hline 0.300 & 4 & 169861.8 & $16.1 \%$ & 12709.5 & 1054.49 & 36.2095 \\
\hline \multirow[t]{3}{*}{0.400} & 5 & 267460.7 & $16.1 \%$ & 12709.5 & 1661.30 & 36.2095 \\
\hline & 6 & 387119.2 & $16.1 \%$ & 12709.5 & 2405.43 & 36.2095 \\
\hline & 7 & 528837.4 & $16.1 \%$ & 12709.5 & 3312.62 & 36.2095 \\
\hline
\end{tabular}

G- Weight of

Weight Everything

$68.23 \quad 40.2095$

$272.90 \quad 40.2095$

$649.62 \quad 40.2095$

$1170.97 \quad 40.2095$

$1844.82 \quad 40.2095$

$2671.16 \quad 40.2095$

$3678.56 \quad 40.2095$ 


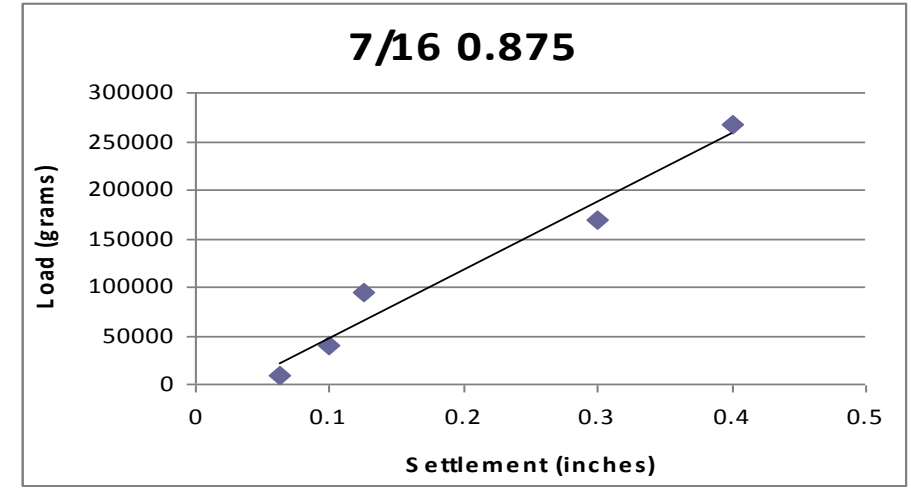

Bearing Capacity: 82.1 psi

d) Number of geofabric: None

Depth of geofabric: Nil

Weights placed: $8 \mathrm{kgs}$

Depth of soil: 3.4 inches

\begin{tabular}{|c|c|c|c|c|c|c|}
\hline Settlement & $\begin{array}{l}\text { Dial } \\
\text { Reading }\end{array}$ & $\begin{array}{l}\text { Force } \\
\text { (grams) }\end{array}$ & $\begin{array}{l}\text { Water } \\
\text { Content }\end{array}$ & $\begin{array}{l}\text { Weight of } \\
\text { Foundation }\end{array}$ & $\begin{array}{l}\text { G- } \\
\text { Weight }\end{array}$ & $\begin{array}{l}\text { Weight of } \\
\text { Everything }\end{array}$ \\
\hline 0.050 & 1 & 6447.1 & $14.5 \%$ & 8695.4 & 709.79 & 32.1954 \\
\hline 0.100 & 2 & 27943.5 & $14.5 \%$ & 8695.4 & 1419.57 & 32.1954 \\
\hline 0.250 & 3 & 64532.3 & $14.5 \%$ & 8695.4 & 2129.36 & 32.1954 \\
\hline 0.425 & 4 & 116213.6 & $14.5 \%$ & 8695.4 & 2839.14 & 32.1954 \\
\hline 0.613 & 5 & 182987.3 & $14.5 \%$ & 8695.4 & 3548.93 & 32.1954 \\
\hline 0.825 & 6 & 264853.6 & $14.5 \%$ & 8695.4 & 4258.72 & 32.1954 \\
\hline 1.25 (Failed) & 7 & 361812.3 & $14.5 \%$ & 8695.4 & 4968.50 & 32.1954 \\
\hline
\end{tabular}

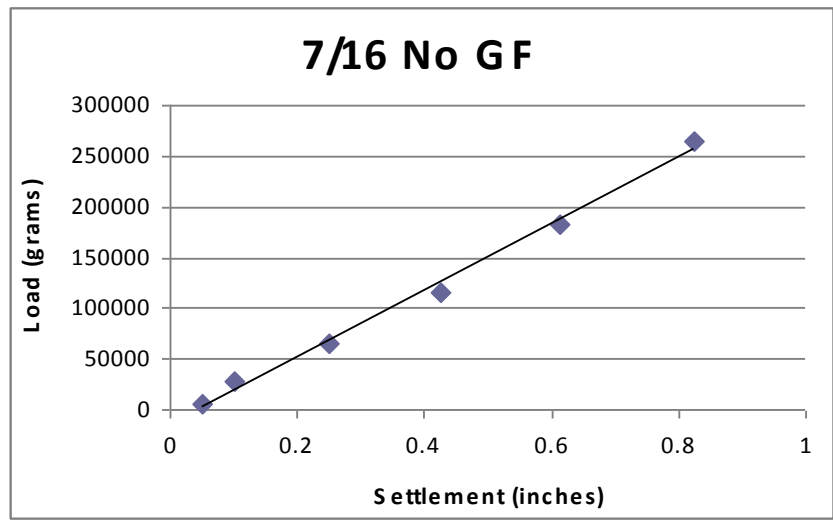

Bearing Capacity: 37.1 psi

e) Number of geofabric: One

Depth of geofabric: 0.425 inch

Weights placed: $8 \mathrm{kgs}$

Depth of soil: 3.4 inches

\begin{tabular}{|c|c|c|c|c|c|c|}
\hline Settlement & $\begin{array}{l}\text { Dial } \\
\text { Reading }\end{array}$ & $\begin{array}{l}\text { Force } \\
\text { (grams) }\end{array}$ & $\begin{array}{l}\text { Water } \\
\text { Content }\end{array}$ & $\begin{array}{l}\text { Weight of } \\
\text { Foundation }\end{array}$ & $\begin{array}{l}\text { G- } \\
\text { Weight }\end{array}$ & $\begin{array}{l}\text { Weight of } \\
\text { Everything }\end{array}$ \\
\hline 0.050 & 1 & 6532.2 & $14.5 \%$ & 8810.1 & 712.31 & 32.3101 \\
\hline 0.075 & 2 & 28312.1 & $14.5 \%$ & 8810.1 & 1424.63 & 32.3101 \\
\hline 0.125 & 3 & 65383.5 & $14.5 \%$ & 8810.1 & 2136.94 & 32.3101 \\
\hline 0.125 & 4 & 117746.5 & $14.5 \%$ & 8810.1 & 2849.26 & 32.3101 \\
\hline 0.175 & 5 & 185401.1 & $14.5 \%$ & 8810.1 & 3561.57 & 32.3101 \\
\hline 0.225 & 6 & 268347.2 & $14.5 \%$ & 8810.1 & 4273.89 & 32.3101 \\
\hline 0.425 & 7 & 366584.9 & $14.5 \%$ & 8810.1 & 4986.20 & 32.3101 \\
\hline
\end{tabular}




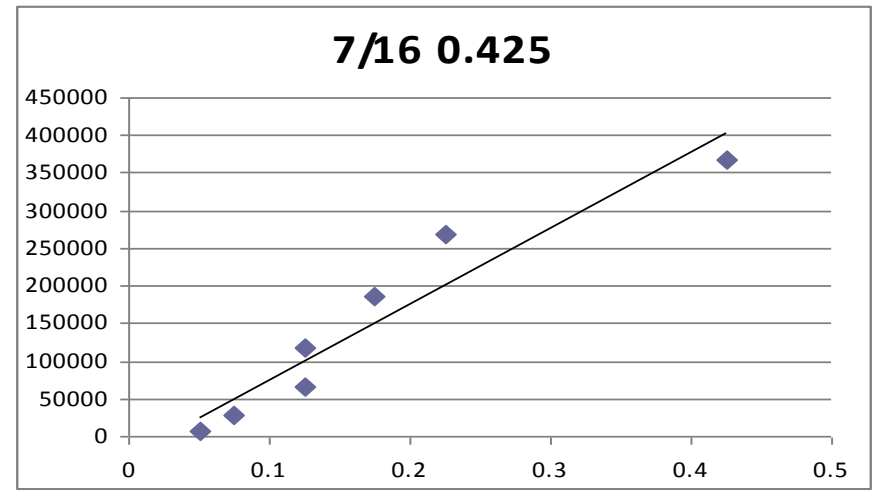

Bearing Capacity: 97.6 psi

f) Number of geofabric: One

Depth of geofabric: 0.875

Weights placed: $8 \mathrm{kgs}$

Depth of soil: 3.4inches

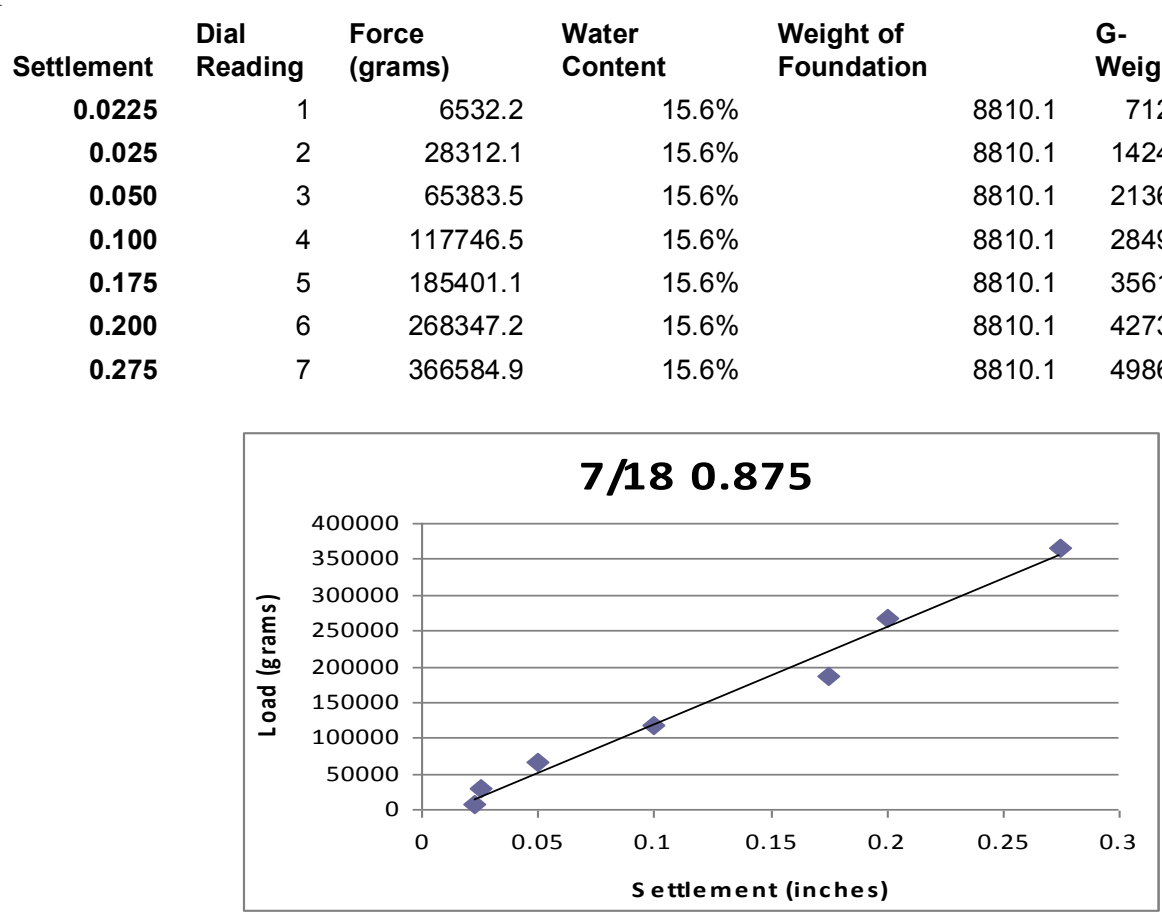

Bearing Capacity: 178.7 psi

g) Number of geofabric: One

Depth of geofabric: 0.425

Weights placed: $8 \mathrm{kgs}$

Depth of soil: 3.4inches

\begin{tabular}{|c|c|c|c|c|c|c|}
\hline Settlement & $\begin{array}{l}\text { Dial } \\
\text { Reading }\end{array}$ & Force (grams) & Water Content & Weight of Foundation & G-Weight & $\begin{array}{l}\text { Weight of } \\
\text { Everything }\end{array}$ \\
\hline 0.025 & 1 & 6447.1 & $15.5 \%$ & 8695.4 & 709.79 & 32.1954 \\
\hline 0.025 & 2 & 27943.5 & $15.5 \%$ & 8695.4 & 1419.57 & 32.1954 \\
\hline 0.050 & 3 & 64532.3 & $15.5 \%$ & 8695.4 & 2129.36 & 32.1954 \\
\hline 0.075 & 4 & 116213.6 & $15.5 \%$ & 8695.4 & 2839.14 & 32.1954 \\
\hline 0.125 & 5 & 182987.3 & $15.5 \%$ & 8695.4 & 3548.93 & 32.1954 \\
\hline 0.20 & 6 & 264853.6 & $15.5 \%$ & 8695.4 & 4258.72 & 32.1954 \\
\hline 0.3125 & 7 & 361812.3 & $15.5 \%$ & 8695.4 & 4968.50 & 32.1954 \\
\hline
\end{tabular}




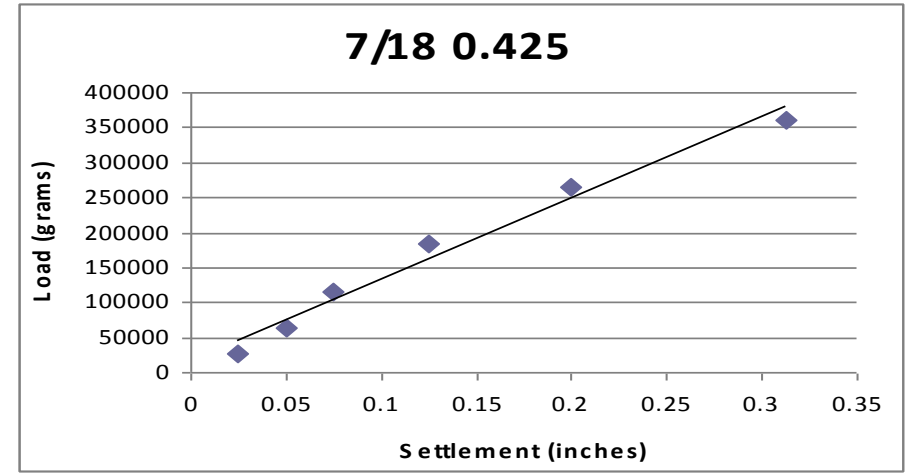

Bearing Capacity: 174.9 psi

h) Number of geofabric: Two

Depth of geofabric: 0.437 inch and 0.875 inch

Weights placed: $8 \mathrm{kgs}$

Depth of soil: 3.4inches

\begin{tabular}{|c|c|c|c|c|c|c|c|}
\hline Settlement & $\begin{array}{l}\text { Dial } \\
\text { Reading }\end{array}$ & $\begin{array}{l}\text { Force } \\
\text { (grams) }\end{array}$ & $\begin{array}{l}\text { Water } \\
\text { Content }\end{array}$ & $\begin{array}{l}\text { Weight of } \\
\text { Foundation }\end{array}$ & & $\begin{array}{l}\text { G- } \\
\text { Weight }\end{array}$ & $\begin{array}{l}\text { Weight of } \\
\text { Everything }\end{array}$ \\
\hline 0.0250 & 1 & 6532.2 & $14.2 \%$ & & 8810.1 & 712.31 & 32.3101 \\
\hline 0.050 & 2 & 28312.1 & $14.2 \%$ & & 8810.1 & 1424.63 & 32.3101 \\
\hline 0.075 & 3 & 65383.5 & $14.2 \%$ & & 8810.1 & 2136.94 & 32.3101 \\
\hline 0.100 & 4 & 117746.5 & $14.2 \%$ & & 8810.1 & 2849.26 & 32.3101 \\
\hline 0.150 & 5 & 185401.1 & $14.2 \%$ & & 8810.1 & 3561.57 & 32.3101 \\
\hline 0.225 & 6 & 268347.2 & $14.2 \%$ & & 8810.1 & 4273.89 & 32.3101 \\
\hline 0.300 & 7 & 366584.9 & $14.2 \%$ & & 8810.1 & 4986.20 & 32.3101 \\
\hline
\end{tabular}

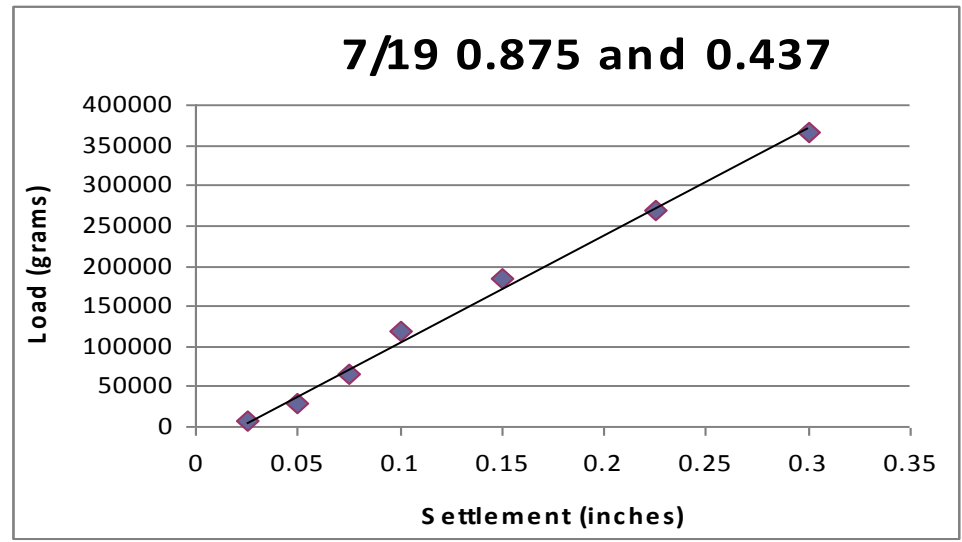

Bearing Capacity: 167.3 psi

i) Number of geofabric: Two

Depth of geofabric: 0.875 inch and 1.75 inch

Weights placed: $8 \mathrm{kgs}$

Depth of soil: 3.4 inches

\begin{tabular}{|c|c|c|c|c|c|c|}
\hline Settlement & $\begin{array}{l}\text { Dial } \\
\text { Reading }\end{array}$ & Force (grams) & Water Content & Weight of Foundation & G-Weight & $\begin{array}{l}\text { Weight of } \\
\text { Everything }\end{array}$ \\
\hline 0.0125 & 1 & 6447.1 & $15.2 \%$ & 8695.4 & 709.79 & 32.1954 \\
\hline 0.025 & 2 & 27943.5 & $15.2 \%$ & 8695.4 & 1419.57 & 32.1954 \\
\hline 0.050 & 3 & 64532.3 & $15.2 \%$ & 8695.4 & 2129.36 & 32.1954 \\
\hline 0.100 & 4 & 116213.6 & $15.2 \%$ & 8695.4 & 2839.14 & 32.1954 \\
\hline 0.200 & 5 & 182987.3 & $15.2 \%$ & 8695.4 & 3548.93 & 32.1954 \\
\hline 0.28 & 6 & 264853.6 & $15.2 \%$ & 8695.4 & 4258.72 & 32.1954 \\
\hline 0.375 & 7 & 361812.3 & $15.2 \%$ & 8695.4 & 4968.50 & 32.1954 \\
\hline
\end{tabular}




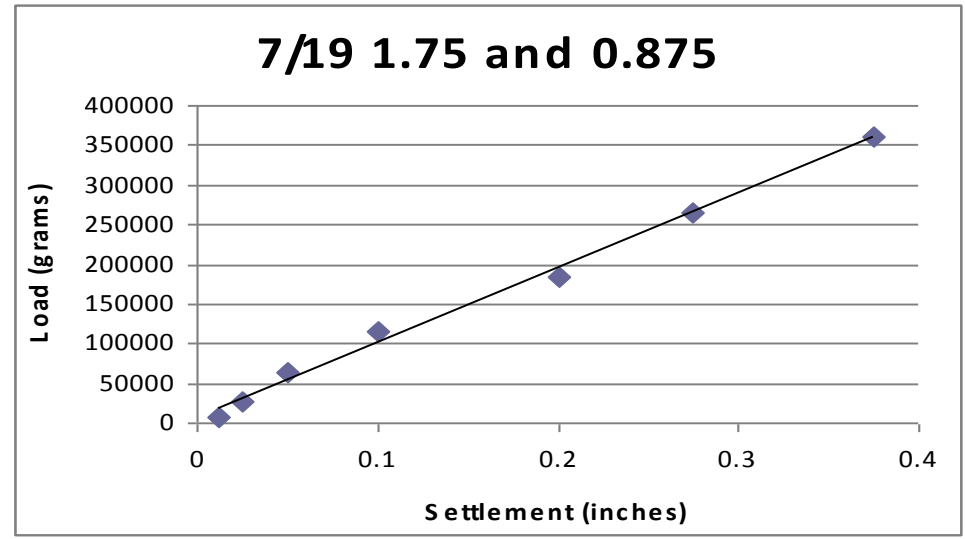

Bearing Capacity: 136.9 psi

j) Number of geofabric: Two

Depth of geofabric: 0.425

Weights placed: $8 \mathrm{kgs}$

Depth of soil: 3.4inches

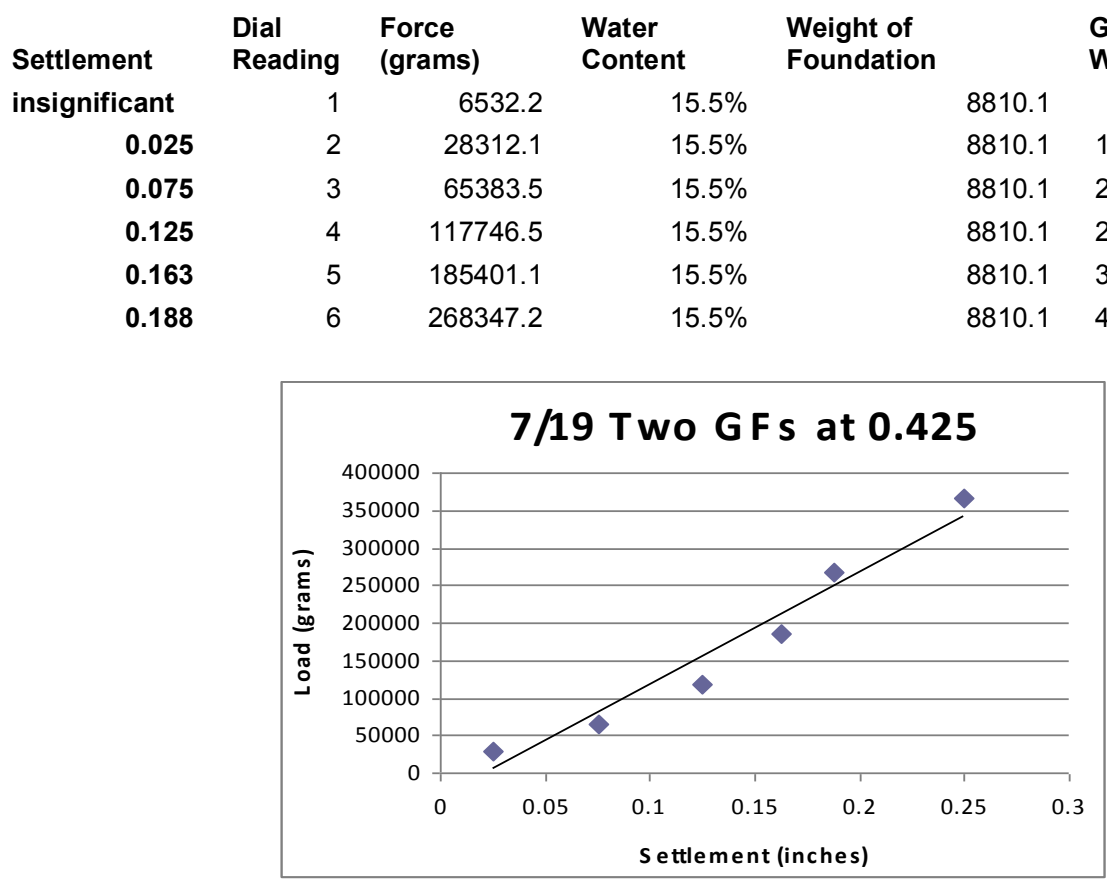

Bearing Capacity: 188.9 psi

k) Number of geofabric: Two

Depth of geofabric: 0.825

Weights placed: $8 \mathrm{kgs}$

Depth of soil: 3.4inches

\begin{tabular}{|c|c|c|c|c|c|c|}
\hline Settlement & $\begin{array}{l}\text { Dial } \\
\text { Reading }\end{array}$ & $\begin{array}{l}\text { Force } \\
\text { (grams) }\end{array}$ & $\begin{array}{l}\text { Water } \\
\text { Content }\end{array}$ & Weight of Foundation & $\begin{array}{l}\text { G- } \\
\text { Weight }\end{array}$ & $\begin{array}{l}\text { Weight of } \\
\text { Everything }\end{array}$ \\
\hline insignificant & 1 & 6447.1 & $15.5 \%$ & 8695.4 & 709.79 & 32.1954 \\
\hline 0.050 & 2 & 27943.5 & $15.5 \%$ & 8695.4 & 1419.57 & 32.1954 \\
\hline 0.075 & 3 & 64532.3 & $15.5 \%$ & 8695.4 & 2129.36 & 32.1954 \\
\hline 0.100 & 4 & 116213.6 & $15.5 \%$ & 8695.4 & 2839.14 & 32.1954 \\
\hline 0.150 & 5 & 182987.3 & $15.5 \%$ & 8695.4 & 3548.93 & 32.1954 \\
\hline 0.15 & 6 & 264853.6 & $15.5 \%$ & 8695.4 & 4258.72 & 32.1954 \\
\hline 0.200 & 7 & 361812.3 & $15.5 \%$ & 8695.4 & 4968.50 & 32.1954 \\
\hline
\end{tabular}

- Weight of

Weight Everything

32.3101

32.3101

32.3101

32.3101

32.3101

32.3101 


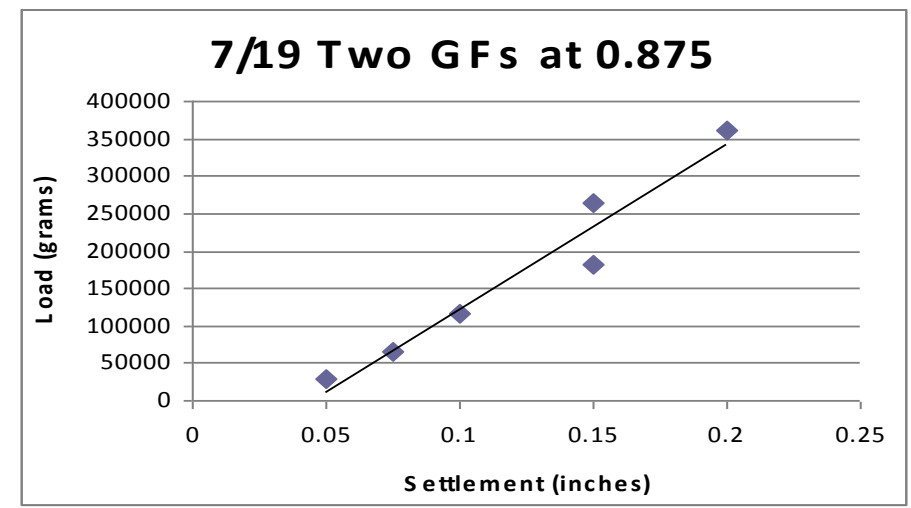

The results could be summarized as:

Bearing Capacity: 242.0 psi

\begin{tabular}{|c|c|c|c|c|c|}
\hline $\begin{array}{c}\text { Water } \\
\text { Content }\end{array}$ & $\begin{array}{c}\text { Depth of Geofabric } \\
\text { (in) }\end{array}$ & $\begin{array}{c}\text { Load at Settlement } 0.2 \text { Inches } \\
\text { (grams) }\end{array}$ & $\begin{array}{c}\text { Load Per Foundation } \\
\text { (lb) }\end{array}$ & $\begin{array}{c}\text { Bearing Capacity } \\
\text { (psi) }\end{array}$ & $\begin{array}{c}\text { Increase in Stength } \\
\text { Compared to no Geofabric }\end{array}$ \\
\hline $15.5 \%$ & 2 at 0.425 & $269,173.7$ & 148.4 & 188.9 & 5.1 \\
\hline $15.5 \%$ & 2 at 0.875 & $344,918.2$ & 190.1 & 242.0 & 6.5 \\
\hline $15.2 \%$ & 0.875 and 1.75 & $195,093.6$ & 107.5 & 136.9 & 3.7 \\
\hline $14.2 \%$ & 0.437 and 0.875 & $238,455.8$ & 131.4 & 167.3 & 4.5 \\
\hline $15.6 \%$ & 0.875 & $254,601.9$ & 140.3 & 178.7 & 4.8 \\
\hline $15.5 \%$ & 0.437 & $249,280.3$ & 137.4 & 174.9 & 4.7 \\
\hline $14.8 \%$ & None & $52,830.2$ & 29.1 & 37.1 & 1.0 \\
\hline $14.3 \%$ & 0.425 & $177,030.2$ & 97.6 & 124.2 & 3.4 \\
\hline $15.8 \%$ & 0.875 & $155,324.0$ & 85.6 & 109.0 & 2.9 \\
\hline $16.1 \%$ & 0.875 & $118,142.4$ & 65.1 & 82.9 & 2.2 \\
\hline $15.1 \%$ & 0.875 & $179,069.1$ & 98.7 & 125.7 & 3.4 \\
\hline
\end{tabular}

VII. Conclusions:

It is observed, like in the earlier cases the bearing capacity increased when the reinforced soil was used, as compared to the model that did not have any geofabric in it. There was no appreciable settlement for the initial dial readings on the centrifuge when reinforced soil was used. As before, failure was determined when the settlement reached around $10 \%$ of the total depth of the soil layer. However, it may be also noted that for a few cases, the foundation got dismantled along with the weights placed over it. This might have happened, if the soil in the top layer was not leveled properly, as then load was not distributed evenly to all the foundations. Besides, it could be possible that that the smaller foundations could not take such heavy loads, as the test did not proceed to higher dial readings when weights of $16 \mathrm{kgs}$ were used. Only for the test when the model did not have the geo fabric placed in soil, settlement crossed $10 \%$ of the total depth of soil. It is to be taken into account that when the geo fabric was placed in the $3.5^{\text {th }}$ layer, which is at 0.425 inches, the bearing capacity increased the most, for the usage of just 1 geo fabric. Another important aspect of these tests was that the settlement increased exponentially with the increase in dial reading on the centrifuge, i.e. with the increase in g-force. In all these cases,. The bearing capacity increased so much owing to the increase in radius of influence from 1.414 (root 2) times the diameter to a larger value when the geo fabric is placed in the soil. Improvement in bearing capacity of reinforced soil over that of unreinforced soil is observed for all positions of reinforcing layers in all tests. The load settlement curves for reinforced soil in all tests continues to rise beyond the failure point of unreinforced soil. This indicates the contribution of reinforcement in resisting bearing pressure. The water content also turned out to be an important factor. Although, we tried to keep the soil at $16 \%$ before the start of the test, it turned out to be less after the test. Since the non woven geo fabric allowed water to pass through it, it got lowered. However, the results differed much for different water content. For soil of high water content, in spite of using the reinforced soil the bearing capacity was lower as compared to reinforced soil of less water content. For the unreinforced soil the settlement went to 1.25 inches. And for all other cases when reinforced soil was used, the settlement hardly reached to $10 \%$ of the total depth of the soil. It is also to be noted that for single layered system, BCR was the maximum when the geo fabric was placed at .25 of the depth of the total soil layer. However, it decreased as the depth of its placement increased. It is so as the failure might have happened above the reinforced layer. For multi layered system, there were insignificant settlements for the first few dial readings on the centrifuge. When two geofabrics were placed together at a single layer as compared to two geofabrics being placed at different layers, the former one gave better results. Besides, the BCR increased significantly. It was 6.5 times when two geo fabrics were placed at $0.25 \mathrm{~d}$ (d: total depth of the soil). When two geo fabrics were 
used at two different layers, it is observed that the two geo fabrics which were placed in close proximity of half a layer and those placed near to the top, i.e. at 0.875 and 0.425 gave better results. For all the cases the graph of settlement vs load, it is linear for the initial phases. Later it starts increasing exponentially. It might be because as with further settlement, the soil gets consolidated and friction develops in the reinforced soil.

\section{Main conclusions:}

Improvement in bearing capacity was observed considerable in reinforced soil over the unreinforced soil. For single layer system, BCR for depth of layer below footing equal to $0.25 \mathrm{~d}$ (d: depth of the soil layer) is maximum and BCR decreases as the depth of layer increases. The reason behind such an increase is attributed to the increase in radius of influence with the aid of geofabrics.

Acknowledgements: For the successful completion of the research, I am grateful to Dr. Jay Meegoda PhD, P.E., Chase Ryan Johnson, Civil and Environmental Engineering dept. of New Jersey Institute Of Technology.

\section{References:}

Dr Jay N. Meegoda Phd, PE, Civil Engg dept, NJIT,Improvement in bearing capacity of soil by geotextiles-an experimental approach by M.S.Ranadive and N.N.Jadhav, Improvement in bearing capacity of soils with geosynthetics by Georg Heerten, Geosynthetic Engineering : Successes, failures and lessons learned by J.P.Giroud, ASTM standards on Geosynthetics, Geosynthetic Engineering by Shukla and Yin, Soil Mechanics and Foundation Engineering by B.C.Punmia 